\title{
Two Cyclodepsipeptides, two Sesquiterpenoids and Other Cytotoxic Metabolites from the Filamentous Fungus Trichothecium sp. (MSX 51320)
}

\author{
Arlene A. Sy-Cordero ${ }^{\dagger}$, Tyler N. Graf ${ }^{\dagger}$, Audrey F. Adcock ${ }^{\ddagger}$, David J. Kroll ${ }^{\ddagger}$, Qi Shen ${ }^{\S}$, Steven \\ M. Swanson ${ }^{\S}$, Mansukh C. Wani ${ }^{\perp}$, Cedric J. Pearcell, and Nicholas H. Oberlies ${ }^{\dagger,}{ }^{*}$ \\ tDepartment of Chemistry and Biochemistry, University of North Carolina at Greensboro, P.O. \\ Box 26170, Greensboro, NC 27402 \\ ¥Department of Pharmaceutical Sciences, BRITE, North Carolina Central University, 1801 \\ Fayetteville St., Durham, NC 27707 \\ $\S$ Department of Medicinal Chemistry and Pharmacognosy, University of Illinois at Chicago, \\ Chicago, IL 60612 \\ ${ }^{\perp}$ Natural Products Laboratory, Research Triangle Institute, P.O. Box 12194 Research Triangle \\ Park, NC 27709
}

"Mycosynthetix, Inc., 505 Meadowland Dr., Suite 103, Hillsborough, NC 27278

\begin{abstract}
Two new cyclodepsipeptides ( $\mathbf{1}$ and $\mathbf{2}$ ), two new sesquiterpenoids ( $\mathbf{3}$ and $\mathbf{4})$, and the known compounds guangomide A (5), roseotoxin $\mathrm{S}$, and three simple trichothecenes were isolated from the cytotoxic organic extract of a terrestrial filamentous fungus, Trichothecium sp. The structures were determined using NMR spectroscopy and mass spectrometry. Absolute configurations of the cyclodepsipeptides were established by employing chiral HPLC, while the relative configurations of $\mathbf{3}$ and $\mathbf{4}$ were determined via NOESY data. The isolation of guangomide A was of particular interest, since it was reported previously from a marine derived fungus.
\end{abstract}

Through our ongoing investigation of diverse organisms for anticancer drug leads, ${ }^{1,2}$ an extract of the fungus Trichothecium sp., from the Mycosynthetix library of filamentous fungi, displayed promising cytotoxicity, with less than $20 \%$ survival of human tumor cells when treated with $20 \mu \mathrm{g} / \mathrm{mL}$ of crude extract. Subsequent bioactivity-directed fractionation studies led to the isolation and characterization of nine secondary metabolites, four of which were new. The isolates could be sub-classified as four depsipeptides (compounds $\mathbf{1}$ and $\mathbf{2}$ being new) and five sesquiterpenoids (compounds $\mathbf{3}$ and $\mathbf{4}$ being new). Furthermore, one of the known cyclodepsipeptides was guangomide A (5), which was described previously from an unidentified marine-derived, rather than in this case a terrestrial, fungus. ${ }^{3}$ Species of the genus Trichothecium have been a rich source of secondary metabolites. ${ }^{4}$ As just one example, at least 29 secondary metabolites have been described from $T$. roseum, ${ }^{4-12}$ ranging from depsipeptides such as the destruxins, roseotoxins and roseocardin, to terpenoids such as eremophilanes, rosenoic acids and trichothecenes, indicative of the vast biosynthetic potential of this, and perhaps, related fungi.

\footnotetext{
*Corresponding Author: To whom correspondence should be addressed. Nicholas_Oberlies@uncg.edu. Tel: 336-334-5474. Supporting Information. ${ }^{1} \mathrm{H}$ and ${ }^{13} \mathrm{C}$ NMR spectra of compounds 1-4. These materials are available free of charge on the Internet at http://pubs.acs.org.
} 
Compound 1 was assigned the molecular formula $\mathrm{C}_{36} \mathrm{H}_{56} \mathrm{~N}_{4} \mathrm{O}_{9}$ via HRESIMS data $(\mathrm{m} / \mathrm{z}$ 711.3923 for $\left[\mathrm{M}+\mathrm{Na}^{+}\right.$), establishing an index of hydrogen deficiency (IHD) of eleven. The ${ }^{1} \mathrm{H}$ and ${ }^{13} \mathrm{C}$ NMR spectra suggested that $\mathbf{1}$ was a depsipeptide-type of compound based on chemical shifts and multiplicities typical for $\alpha$ protons and carbons (Table 1). In general, cyclodepsipeptides are secondary metabolites that contain amino acids and at least one hydroxy acid linked through ester and amide bonds to form a cyclic structure. ${ }^{1} \mathrm{H}$ NMR data (Table 1) revealed the presence of five aromatic protons $\left(\delta_{\mathrm{H}} 7.19-7.26\right.$ for $\mathrm{H}-5$ to H-9), suggesting a phenylalanine (Phe) residue. Six $\alpha$ protons were also evident $\left(\delta_{\mathrm{H}} 5.45,5.29\right.$, $4.73,4.65,4.52$, and 3.45 for $\mathrm{H}-11, \mathrm{H}-2, \mathrm{H}-22, \mathrm{H}-17, \mathrm{H}-25$, and $\mathrm{H}-31$, respectively).

Moreover, three $\mathrm{NH}$ protons $\left(\delta_{\mathrm{H}} 7.93,7.46\right.$, and 5.92) and a $\mathrm{N}$-methyl group $\left(\delta_{\mathrm{H}} 3.06\right)$ were observed, as were signals evident of an $\mathrm{O}-\mathrm{CH}_{2}$ moiety $\left(\delta_{\mathrm{H}} 4.21\right.$ and $\left.4.05, \mathrm{H}_{2}-23\right)$. Most other resonances were found in the upfield region of the ${ }^{1} \mathrm{H}$ NMR spectrum, including those for both methylene and methine protons $\left(\delta_{\mathrm{H}} 2.98,2.84,1.95,1.34\right.$ and a multiplet from 1.71 - 1.53) and eight doublet methyl resonances $\left(\delta_{\mathrm{H}} 0.91,0.90,1.02,1.01,0.87,0.93,0.81\right.$, and 0.78 , for $\mathrm{H}_{3}-14, \mathrm{H}_{3}-15, \mathrm{H}_{3}-19, \mathrm{H}_{3}-20, \mathrm{H}_{3}-28, \mathrm{H}_{3}-29, \mathrm{H}_{3}-34$, and $\mathrm{H}_{3}-35$, respectively). HSQC data further confirmed the presence of five $\mathrm{CH}_{2}$ resonances $\left(\mathrm{H}_{2}-3, \mathrm{H}_{2}-12, \mathrm{H}_{2}-26\right.$, $\mathrm{H}_{2}-32$ ), including an oxymethylene $\left(\mathrm{H}_{2}-23\right)$, and eight methyl groups. Data from the ${ }^{13} \mathrm{C}$ and DEPT-135 NMR spectra indicated 36 carbon resonances, consistent with the molecular formula, including six ester and/or amide carbonyl carbons $\left(\delta_{\mathrm{C}} 172.4,171.9,170.5,170.2\right.$, 169.7, and 167.8, for C-1, C-24, C-30, C-21, C-10, and C-16, respectively), six aromatic carbons $\left(\delta_{\mathrm{C}} 135.8,129.4 \times 2,128.5 \times 2,127.1\right.$, for positions $\mathrm{C}-4$ to $\left.\mathrm{C}-9\right)$, three oxygenated carbons $\left(\delta_{\mathrm{C}} 79.0,73.5\right.$, and 63.4 , for $\mathrm{C}-17, \mathrm{C}-11$, and $\mathrm{C}-23$, respectively) and four nitrogenbearing carbons $\left(\delta_{\mathrm{C}} 65.1,54.9,51.7,50.1\right.$, for C-31, C-22, C-25, and C-2, respectively). COSY data (Figure 1) were key in the establishment of spin systems, leading to the identification of the hydroxy and amino acid residues. Some of the prominent spin systems include a Phe moiety (from NH at $\delta 7.46$ to $\mathrm{H}-2$ and $\mathrm{H}-3$, and from $\mathrm{H}-5$ to H-9), a hydroxyisocaproic acid (Hic) moiety (from $\mathrm{H}-11$ to $\mathrm{H}_{3}-15$ ), a hydroxyisovaleric acid (Hiv) moiety (from $\mathrm{H}-17$ to $\mathrm{H}_{3}-20$ ), a serine (Ser) moiety (from NH at $\delta 7.93$ to H-22 and $\mathrm{H}-23$ ), a leucine (Leu) moiety (from $\mathrm{NH}$ at $\delta 5.92$ to $\mathrm{H}-25$ through $\mathrm{H}_{3}-29$ ), and a second leucine (Leu) moiety (from H-31 to H-35). The lack of COSY correlations from any NH signal to the $\alpha$-proton of the latter Leu system suggested an NMe group, which was supported by the upfield chemical shift of this proton $\left(\delta_{\mathrm{H}} 3.45 ; \mathrm{H}-31\right) ;{ }^{3}$ indeed, an HMBC correlation from an NMe group $\left(\mathrm{H}_{3}-36\right)$ to $\mathrm{C}-31$ confirmed this assignment. $\mathrm{HMBC}$ correlations from $\mathrm{H}_{2}-3$ to the aromatic carbons C-4, C-5, and C-9 revealed the presence of Phe, while correlations from each $\alpha$-proton and $\mathrm{NH}$ proton to each carbonyl carbon helped establish the connectivities in the core of the structure (Figure 1). HMBC correlations from $\mathrm{H}-2$ to $\mathrm{C}-1$, $\mathrm{C}-3$, and $\mathrm{C}-10$, from the $\mathrm{NH}$ proton at $\delta 7.46$ to $\mathrm{C}-10$ and $\mathrm{C}-2$, and from $\mathrm{H}-11$ to $\mathrm{C}-10$ suggested that Hic acylates Phe; correlations from H-11, H-17 and H-18 to C-16 suggested that Hiv acylates Hic; correlations from H-17, H-22 and H-23 to C-21 suggested that Ser acylates Hiv; correlations from the $\mathrm{NH}$ proton at $\delta 7.93$, and $\mathrm{H}-25$ to $\mathrm{C}-24$ suggested that Leu acylates Ser; correlations from the NH proton at $\delta 5.92$ and $\mathrm{H}-31$ to C-30 suggested that NMeLeu acylates Leu; and correlations from $\mathrm{H}_{2}-3$ and $\mathrm{H}_{3}-36$ to $\mathrm{C}-1$ suggested that Phe acylates the NMeLeu. These connectivities confirmed the cyclic hexadepsipeptide nature of compound $\mathbf{1}$, thereby satisfying the IHD. 

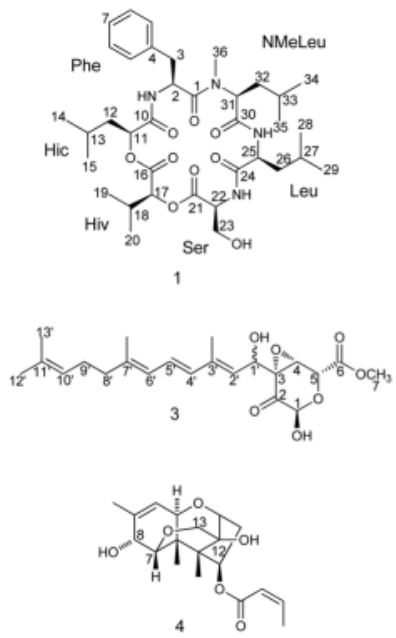
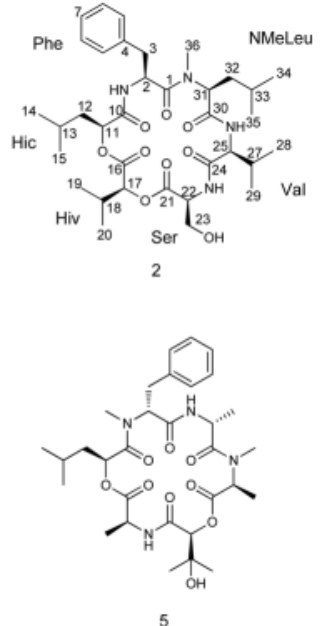

Compound 2 was assigned the molecular formula $\mathrm{C}_{35} \mathrm{H}_{54} \mathrm{~N}_{4} \mathrm{O}_{9}$ on the basis of HRESIMS data $\left(\mathrm{m} / z 697.3770\right.$ for $\left.[\mathrm{M}+\mathrm{Na}]^{+}\right)$, establishing an IHD of eleven. It had a spectroscopic profile similar to 1, but differences were apparent in the ${ }^{13} \mathrm{C}$ and DEPT-135 NMR data, where $\mathbf{2}$ displayed one less methylene than $\mathbf{1}$. This finding was supported by the HRESIMS data of $\mathbf{2}$, which was 14 amu less than $\mathbf{1}$. Further analyses of the 2D NMR data revealed that $\mathbf{2}$ contained the amino acid valine ( $\mathrm{Val}$ ), instead of the Leu unit present in 1, that acylates Ser. This was apparent from the signals for the isopropyl unit (H-27 to H-29) connected to the $\alpha$ carbon at C-24, as observed via HMBC and COSY correlations.

The absolute configurations of the $\alpha$ carbons of compounds $\mathbf{1}$ and $\mathbf{2}$ were determined via chiral HPLC analyses performed on the hydrolysis products. ${ }^{13-15}$ For the organic extracts of the acid hydrolysates, comparison of retention times with those of standard hydroxy acids revealed the Hiv and Hic units of $\mathbf{1}$ and $\mathbf{2}$ to both be of the L-configuration. All four amino acids were determined to be of the L-configuration in both $\mathbf{1}$ and $\mathbf{2}$ by a similar analysis of the aqueous extracts of the acid hydrolysates. The closest known compound to these new cyclodepsipeptides was hirsutatin A, which was isolated from the pathogenic fungus, Hirsutella nivea. ${ }^{13}$ However, hirsutatin A differs due to a L-threonine unit instead of L-Leu (1) or L-Val (2) units. The new isolates were ascribed the trivial names trichodepsipeptide A (1) and trichodepsipeptide B (2) due to their isolation from Trichothecium sp.

Compound 3 was ascribed a molecular formula of $\mathrm{C}_{22} \mathrm{H}_{32} \mathrm{O}_{8}$ based on HRESIMS data $(\mathrm{m} / \mathrm{z}$ 447.1981 for $[\mathrm{M}+\mathrm{Na}]^{+}$), indicating an IHD of seven. The ${ }^{1} \mathrm{H}$ NMR data (see experimental) showed the presence of five olefinic protons $\left(\delta_{\mathrm{H}} 6.47,6.11,5.85,5.28\right.$, and 5.06 for $\mathrm{H}-5^{\prime}$, $\mathrm{H}-4^{\prime}, \mathrm{H}-6^{\prime}, \mathrm{H}-2^{\prime}$, and $\mathrm{H}-10^{\prime}$, respectively), four oxygenated methine protons ( $\delta_{\mathrm{H}} 5.23,5.19$, 4.63, and 3.82 for $\mathrm{H}-1, \mathrm{H}-1^{\prime}, \mathrm{H}-5$, and $\mathrm{H}-4$, respectively), one methoxy group $\left(\delta_{\mathrm{H}} 3.74, \mathrm{H}-7\right)$, four methylene protons $\left(\delta_{\mathrm{H}} 2.08\right.$ for $\mathrm{H}_{2}-8^{\prime}$ and $\left.\mathrm{H}_{2}-9^{\prime}\right)$, and four vinyl methyl groups $\left(\delta_{\mathrm{H}}\right.$ 1.92, 1.77, 1.66, and 1.58 for $\mathrm{CH}_{3}-3^{\prime}, \mathrm{CH}_{3}-7^{\prime}, \mathrm{CH}_{3}-13^{\prime}$, and $\mathrm{CH}_{3}-12^{\prime}$, respectively). The ${ }^{13} \mathrm{C}$ and DEPT-135 data revealed 22 carbons, consistent with the molecular formula and indicative of two carbonyl carbons, likely a ketone and an ester $\left(\delta_{\mathrm{C}} 193.6\right.$ and 170.8 , for C-2 and C-6, respectively), eight olefinic carbons $\left(\delta_{\mathrm{C}} 140.6,140.1,134.2,132.0,126.4,125.7\right.$, 125.1, and 124.0 for C-7', C-3', C-4', C-11', C-5', C-2', C-6', and C-10', respectively), six oxygenated carbons, including that of a methoxy signal $\left(\delta_{\mathrm{C}} 99.3,61.5,64.4,65.9,56.8\right.$, and 56.1 for C-1, C-3, C-1', C-5, C-7, and C-4, respectively), two methylenes ( $\delta_{\mathrm{C}} 40.3$ and 26.8

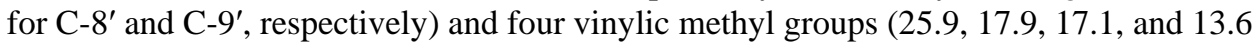
for C-13', C-12', $\mathrm{CH}_{3}-7^{\prime}$ and $\mathrm{CH}_{3}-3^{\prime}$, respectively). COSY data (Figure 2) identified four spin systems, for example those from $\mathrm{H}_{2}-8^{\prime}$ to $\mathrm{H}-10^{\prime}$, from $\mathrm{H}-4^{\prime}$ to $\mathrm{H}-6^{\prime}$, from $\mathrm{H}-1^{\prime}$ to $\mathrm{H}-2^{\prime}$, and from $\mathrm{H}-4$ to $\mathrm{H}-5$; the $J$ value of $15 \mathrm{~Hz}$ for coupling between $\mathrm{H}-4^{\prime}$ and $\mathrm{H}-5^{\prime}$ verified a 
trans double bond. A sesquiterpenoid side chain was apparent from HMBC correlations from $\mathrm{H}-1^{\prime}$ to $\mathrm{H}-13$ ' (Figure 2). The point of attachment for the side chain was evident from HMBC correlations from $\mathrm{H}-2^{\prime}$ to $\mathrm{C}-3$, and from $\mathrm{H}-1^{\prime}$ to $\mathrm{C}-2, \mathrm{C}-4$, and $\mathrm{C}-3$, suggesting that the quaternary carbon $\mathrm{C}-3$ was connected directly to $\mathrm{C}-1^{\prime}$ and flanked by the ketone carbonyl C-2 and the oxygenated C-4. HMBC correlations from $\mathrm{H}-1$ to C-2, C-3, and C-5, and from $\mathrm{H}-5$ to $\mathrm{C}-1$ suggested that the anomeric proton $(\mathrm{H}-1)$ was connected to $\mathrm{C}-2$ and $\mathrm{C}-5$; the latter was via an ether linkage, thereby satisfying the oxygen atoms required by the molecular formula. Finally, correlations from H-4 to C-3, C-5, and C-6, from H-5 to C-6, and from $\mathrm{H}_{3}-7$ to $\mathrm{C}-6$ established the six-membered ring with the carboxymethyl group attached at $\mathrm{C}-5$. The sesquiterpenoid chain $\left(\mathrm{C}-1^{\prime}\right.$ to $\left.\mathrm{C}-12^{\prime}\right)$ with a conjugated triene was similar to the oligosporon group of compounds, which were isolated from the nematodetrapping fungus Arthrobotrys oligospora. ${ }^{16}$ However, compound $\mathbf{3}$ had a unique ring portion that was derived from a sugar unit (hexanose). Compound $\mathbf{3}$ was ascribed the trivial name trichothosporon A.

The relative configuration of $\mathbf{3}$ was determined via a NOESY experiment. This revealed that $\mathrm{H}-5$ and $\mathrm{H}-4$ were on the same face of the ring. Moreover, a correlation between $\mathrm{H}-1$ and the methoxy moiety of the ester showed these were on the opposite face. Unfortunately, it was not possible to determine the relative configuration at $\mathrm{H}-\mathrm{1}^{\prime}$ unambiguously through the same experiment. Several unsuccessful reactions were attempted, resulting in decomposition of compound 3 . Thus, the absolute configuration remains undetermined at this time.

Compound $4\left(\mathrm{C}_{19} \mathrm{H}_{26} \mathrm{O}_{6}\right.$ by HRMS $)$ was a new trichothecene analogue, which was related in structure to a previously reported (and unnamed) synthetic intermediate. ${ }^{17}$ Based on NMR data, compound 4 retained the core of the trichothecene structure, but key signals for the epoxide moiety were replaced by a methylene unit $\left(\mathrm{H}_{2}-13\right)$. The geminal coupling constant of these protons $(J=12 \mathrm{~Hz})$ was too large for an epoxide moiety (typically $4 \mathrm{~Hz}$ ), suggesting a larger ring system. HMBC data indicated the presence of either a tetrahydropyran ring (connecting $\mathrm{C}-7$ to $\mathrm{C}-13$ and the formation of a tertiary alcohol at C-12) or a tetrahydrofuran ring (connecting C-7 to C-12 with a free $\mathrm{CH}_{2} \mathrm{OH}$ at C-13). Chemical shifts of the methylene group at $\mathrm{C}-13$ were consistent with the former. ${ }^{17}$ Furthermore, acetyltion with pyridine-acetic anhydride resulted in the incorporation of only one acetyl group, indicating that $\mathbf{4}$ had only one $\mathrm{OH}$ group susceptible to the reaction (i.e. position 8). NOESY data showed correlations between $\mathrm{H}-11$ and $\mathrm{H}_{2}-13$, which suggested that these protons were on the same face of the molecule, while the broad singlet signals for $\mathrm{H}-7$ and H-8, together with their NOESY correlations, suggested that $\mathrm{H}-7$ and $\mathrm{H}-8$ were on the opposite face of the molecule from $\mathrm{H}-11$.

Five other known compounds - guangomide A (5), ${ }^{3}$ roseotoxin $\mathrm{S},{ }^{18}$ crotocin, ${ }^{17,19}$ trichothecinol $\mathrm{B},{ }^{20}$ and trichothecin, ${ }^{4,19}$ were isolated and elucidated; in all cases, the structural data were in agreement with the literature. The identification of the cyclodepsipeptide 5 was of particular interest as it was described initially from an unidentified fungal strain isolated from an Ianthella sponge. ${ }^{3}$ The NMR data of $\mathbf{5}$ was identical to the literature (see Supporting Information), although comparison of the optical rotation showed opposite signs (literature: -44.6 vs. compound 5: +6.5 ). Crystals of 5 suitable for X-ray crystallographic analysis were generated, which were identical to the literature as well (data not shown). This could mean that $\mathbf{5}$ was either guangomide A or its enantiomer. Amino acid analysis and Marfey's derivatization of the acid hydrolysis products of 5 showed the same amino acid residues as reported for guangomide A, particularly LNMeAla and D-NMePhe (see Supporting Information for UPLC chromatograms of the amino acid analyses). Thus, compound $\mathbf{5}$ was presumed to be guangomide $\mathrm{A} ;{ }^{3}$ the difference in optical rotation values cannot be explained at this time. To the best of our knowledge, this is the first description of $\mathbf{5}$ from a terrestrial organism. Crews and colleagues reported weak 
antibacterial activity for $\mathbf{5}$ vs. Staphylococcus epidermidis and Enterococcus durans (MIC values of $100 \mu \mathrm{g} / \mathrm{mL}$ in both assays). ${ }^{3}$ The same authors reported $\mathbf{5}$ as inactive against murine and human tumor cell lines in a disk diffusion assay. In the human tumor panel, $\mathbf{5}$ displayed $\mathrm{EC}_{50}$ values of approximately $15 \mu \mathrm{M}$ against MCF-7, H460, and SF268 cell lines.

The new compounds (1-4) were not active in the human tumor panel (i.e. $\mathrm{IC}_{50}$ values $>10$ $\mu \mathrm{M}$ against all cell lines). Thus, roseotoxin $\mathrm{S}$ and the trichothecene analogues likely account for the cytotoxicity observed with the crude extract. Our team reported recently a procedure to dereplicate macrocyclic trichothecenes, ${ }^{21}$ and studies are ongoing to augment those methods for simple trichothecenes. Regardless, the biosynthetic potential of this fungus was quite intriguing, given the variety of structural types isolated on a non-optimized culture that was collected over two decades ago.

\section{EXPERIMENTAL SECTION}

\section{General Experimental Procedures}

UV spectra and optical rotations were acquired on a Varian Cary 100 Bio UV-Vis spectrophotometer and a Rudolph Research Autopol III polarimeter, respectively. NMR spectra were recorded on a JEOL ECA-500, operating at $500 \mathrm{MHz}$ for ${ }^{1} \mathrm{H}$ and $125 \mathrm{MHz}$ for ${ }^{13} \mathrm{C}$. HPLC was carried out using a Varian Prostar HPLC system equipped with ProStar 210 pumps and a Prostar 335 photodiode array detector, with data collected and analyzed using Galaxie Chromatography Workstation software (version 1.9.3.2). For preparative HPLC, a YMC ODS-A $(5 \mu \mathrm{m} ; 250 \times 20 \mathrm{~mm})$ column was used with a $10 \mathrm{~mL} / \mathrm{min}$ flow rate; for the semi-preparative HPLC, a YMC ODS-A $(5 \mu \mathrm{m} ; 250 \times 10 \mathrm{~mm})$ column was used with a $5 \mathrm{~mL} / \mathrm{min}$ flow rate; for analytical HPLC, YMC ODS-A $(5 \mu \mathrm{m} ; 150 \times 4.6 \mathrm{~mm})$ columns were used with a $1 \mathrm{~mL} / \mathrm{min}$ flow rate (all from Waters). For analytical HPLC, MetaTherm HPLC column temperature controllers (Varian) maintained these columns at $30^{\circ} \mathrm{C}$.

Reversed-phase chiral HPLC was carried out using a Chirex 3126 D-penicillamine ( $5 \mu \mathrm{m}$; $150 \times 4.6 \mathrm{~mm}$ ) column at $1 \mathrm{~mL} / \mathrm{min}$ flow rate (Phenomenex). UPLC was carried out on a Waters Acquity UPLC system (Waters; Milford MA) using a Waters HSS T3 C18 column $(1.8 \mu \mathrm{m} ; 2.1 \times 100 \mathrm{~mm})$ maintained at $40^{\circ} \mathrm{C}$. HRESIMS on compounds $\mathbf{1 - 3}$ were performed by direct injection coupled to QtofMS using a Waters SYNAPT MS system;

HRMALDITOFMS data for compound $\mathbf{4}$ and $\mathbf{5}$ were acquired with an Applied Biosystems TOF/TOF mass spectrometer using conditions described previously. ${ }^{22}$ Flash chromatography was conducted using a CombiFlash Rf system using RediSep Rf Si-gel columns (both from Teledyne-Isco).

\section{Producing Organism and Fermentation}

Mycosynthetix fungal strain 51320 was isolated by Dr. Barry Katz of MYCO search in September of 1990 from leaf litter collected in Leon County, approximately 2 miles eastsoutheast of Tallahassee, FL. DNA analyses were performed by MIDI Labs, Inc. (Newark, DE), and the D2 variable region of the Large Subunit (LSU) rRNA was sequenced and compared to their database. This analysis suggested that this fungus was related to Trichothecium sp. (Order Hypocreales); these data were deposited in Genbank (accession No. JF930284). The culture was stored on a malt extract slant and was transferred periodically. A fresh culture was grown on a similar slant, and a piece was transferred to a medium containing $2 \%$ soy peptone, $2 \%$ dextrose, and $1 \%$ yeast extract (YESD media). Following incubation $(7 \mathrm{~d})$ at $22{ }^{\circ} \mathrm{C}$ with agitation, the culture was used to inoculate $50 \mathrm{~mL}$ of a rice medium, prepared using rice to which was added a vitamin solution and twice the volume of rice with $\mathrm{H}_{2} \mathrm{O}$, in a $250 \mathrm{~mL}$ Erlenmeyer flask. This was incubated at $22{ }^{\circ} \mathrm{C}$ until the culture showed good growth (approximately $14 \mathrm{~d}$ ). The scale up culture was grown in a 
2.8 $\mathrm{L}$ Fernbach flask containing $150 \mathrm{~g}$ rice and $300 \mathrm{~mL} \mathrm{H}_{2} \mathrm{O}$ and was inoculated using a seed culture grown in YESD medium. This was incubated at $22{ }^{\circ} \mathrm{C}$ for $14 \mathrm{~d}$.

\section{Extraction and Isolation}

To the large scale solid fermentation were added $500 \mathrm{~mL}$ of $1: 1 \mathrm{MeOH} / \mathrm{CHCl}_{3}$. The mixture was shaken for $24 \mathrm{~h}$ then filtered, and the solvent was evaporated (waxy yellow solid). This crude extract was partitioned between $\mathrm{CHCl}_{3} / \mathrm{MeOH} / \mathrm{H}_{2} \mathrm{O}$ (4:1:5), and the organic soluble material was dried and further partitioned between hexanes and $\mathrm{CH}_{3} \mathrm{CN}(1: 1)$. The $\mathrm{CH}_{3} \mathrm{CN}$ partition ( $4 \mathrm{~g})$ was fractionated via flash chromatography using silica gel via a hexanes/ $\mathrm{CHCl}_{3} / \mathrm{MeOH}$ gradient to afford four fractions. Fraction two $(1.5 \mathrm{~g})$, which eluted with 0 to $10 \% \mathrm{MeOH}$ in $\mathrm{CHCl}_{3}$ over 14 min, was separated further by reversed-phase HPLC (20$100 \% \mathrm{CH}_{3} \mathrm{CN}-\mathrm{H}_{2} \mathrm{O}$ over $100 \mathrm{~min}$ ) to obtain 18 fractions. Fraction 13 yielded guangomide $\mathrm{A}$ $(4 ; 91 \mathrm{mg})$. Fraction $14(11.4 \mathrm{mg})$ was purified by semi-preparative reversed-phase HPLC $\left(20-100 \% \mathrm{CH}_{3} \mathrm{CN}-\mathrm{H}_{2} \mathrm{O}\right.$ over $\left.15 \mathrm{~min}\right)$ to yield trichothosporon $\mathrm{A}(3,3 \mathrm{mg})$. Fraction 16 (9.4 $\mathrm{mg}$ ) was separated further by semi-preparative reversed-phase HPLC $\left(20-100 \% \mathrm{CH}_{3} \mathrm{CN}\right.$ $\mathrm{H}_{2} \mathrm{O}$ over $\left.15 \mathrm{~min}\right)$ to obtain trichodepsipeptide $\mathrm{B}(2 ; 4 \mathrm{mg})$, while similar separation conditions were utilized on Fraction $17(18 \mathrm{mg})$ to yield trichodepsipeptide A $(\mathbf{1} ; 7 \mathrm{mg})$. An initial sample of this same fungus was processed in the same fashion to yield a $\mathrm{CH}_{3} \mathrm{CN}$ partition $(672 \mathrm{mg})$, which was subjected to flash chromatography using silica gel via a hexanes $/ \mathrm{CHCl}_{3} / \mathrm{MeOH}$ gradient to afford seven fractions. Fraction $5(490 \mathrm{mg})$ was separated further by preparative reversed-phase HPLC $\left(20-100 \% \mathrm{CH}_{3} \mathrm{CN}-\mathrm{H}_{2} \mathrm{O}\right.$ over 100 min) to yield a new trichothecene analogue $(4 ; 17 \mathrm{mg})$, trichothecin $(6 \mathrm{mg})$, crotocin $(7 \mathrm{mg})$, a mixture of roseotoxin $\mathrm{S}$ and trichothecinol B $(16 \mathrm{mg})$, guangomide $\mathrm{A}(5 ; 22 \mathrm{mg})$, and trichothosporon A $(3 ; 22 \mathrm{mg})$.

Trichodepsipeptide A (1)—white powder; $[\alpha]^{\mathrm{D}_{25}}-45.6\left(c 0.3, \mathrm{CHCl}_{3}\right) ; \mathrm{UV}(\mathrm{MeOH})$ $\lambda_{\max }(\log \varepsilon)=206(2.97) ;{ }^{1} \mathrm{H},{ }^{13} \mathrm{C}$ NMR, and HMBC data, see Table 1 ; HRESIMS $\mathrm{m} / z$ $711.3923[\mathrm{M}+\mathrm{Na}]^{+}$calcd. for $\mathrm{C}_{36} \mathrm{H}_{56} \mathrm{~N}_{4} \mathrm{O}_{9} \mathrm{Na}, 711.3945$.

Trichodepsipeptide B (2)—white powder; $[\alpha]^{\mathrm{D}}{ }_{25}-79.0\left(c 0.1, \mathrm{CHCl}_{3}\right) ; \mathrm{UV}(\mathrm{MeOH})$ $\lambda_{\max }(\log \varepsilon)=203(2.67) ;{ }^{1} \mathrm{H},{ }^{13} \mathrm{C}$ NMR and HMBC data, see Table 1; HRESIMS $\mathrm{m} / z$ $697.3770[\mathrm{M}+\mathrm{Na}]^{+}$, calcd. for $\mathrm{C}_{35} \mathrm{H}_{54} \mathrm{~N}_{4} \mathrm{O}_{9} \mathrm{Na}, 697.3788$.

Trichothosporon A (3)—white powder; $[\alpha]^{\mathrm{D}_{25}}-8.8\left(c 0.1, \mathrm{CHCl}_{3}\right) ;{ }^{1} \mathrm{H}$ NMR $(500 \mathrm{MHz}$, $\left.\mathrm{CDCl}_{3}\right) \delta 5.23(\mathrm{~s}, \mathrm{H}-1), 3.82(\mathrm{~d}, J=3, \mathrm{H}-4), 4.63$ (d, $\left.J=3, \mathrm{H}-5\right), 3.74$ (s, H-7), 5.19 (d, $J=$ 9, H-1'), 5.28 (d, $\left.J=9, \mathrm{H}-2^{\prime}\right), 6.11$ (d, $\left.J=15, \mathrm{H}-4^{\prime}\right), 6.47$ (dd, $\left.J=15,11, \mathrm{H}-5^{\prime}\right), 5.85$ (d, $J=$ 11, H-6'), 2.08 (m, H-8'), 2.08 (m, H-9'), 5.06 (m, H-10'), 1.58 (s, H-12'), 1.66 (s, H-13'), $1.92\left(\mathrm{~d}, J=1,3^{\prime}-\mathrm{CH}_{3}\right), 1.77\left(\mathrm{~s}, 7^{\prime}-\mathrm{CH}_{3}\right) ;{ }^{13} \mathrm{C}$ NMR $\left(125 \mathrm{MHz}, \mathrm{CDCl}_{3}\right) \delta 99.3(\mathrm{C}-1), 193.6$ (C-2), 61.5 (C-3), 56.1 (C-4), 65.9 (C-5), 170.8 (C-6), 56.8 (C-7), 64.4 (C-1'), 125.7 (C-2'), $140.1\left(\mathrm{C}-3^{\prime}\right), 134.2\left(\mathrm{C}-4^{\prime}\right), 126.4\left(\mathrm{C}-5^{\prime}\right), 125.1\left(\mathrm{C}-6^{\prime}\right), 140.6\left(\mathrm{C}-7^{\prime}\right), 40.3\left(\mathrm{C}-8^{\prime}\right), 26.8\left(\mathrm{C}-9^{\prime}\right)$, $124.0\left(\mathrm{C}-10^{\prime}\right), 132.0\left(\mathrm{C}-11^{\prime}\right), 17.9\left(\mathrm{C}-12^{\prime}\right), 25.9\left(\mathrm{C}-13^{\prime}\right), 13.6\left(3^{\prime}-\mathrm{CH}_{3}\right), 17.1\left(7^{\prime}-\mathrm{CH}_{3}\right)$; HRESIMS $m / z, 447.1981\left[\mathrm{M}+\mathrm{Na}^{+}\right.$, calcd. for $\mathrm{C}_{22} \mathrm{H}_{32} \mathrm{O}_{8} \mathrm{Na}, 447.1995$.

Trichothecene analogue (4)-colorless film; $[\alpha]^{\mathrm{D}}{ }_{25}-11.0\left(c 0.1, \mathrm{CHCl}_{3}\right) ;{ }^{1} \mathrm{H} \mathrm{NMR}$ $\left(500 \mathrm{MHz}, \mathrm{CDCl}_{3}\right) \delta 6.35$ (dq, $\left.J=11.5,7.5, \mathrm{H}-3^{\prime}\right), 5.77$ (dq, $\left.J=11.5,2, \mathrm{H}-2^{\prime}\right), 5.58(\mathrm{~d}, J=6$, H-10), 5.51 (dd, $J=8,3.4, \mathrm{H}-4$ ), 4.20 (d, $J=5$, H-2), 3.95 (br.s., H-8), 3.92 (d, $J=12$, Ha-13), 3.83 (br.s., H-7), 3.63 (d, $J=7, \mathrm{H}-11$ ), 3.61 (d, $J=12$, Hb-13), 2.39 (dd, $J=15.5$, 8.6, Ha-3), 2.12 (m, Hb-3), 2.11 (dd, $J=7.5,2, \mathrm{H}-4^{\prime}$ ), 1.84 (s, H $\left.\mathrm{H}_{3}-16\right), 1.03$ (s, H3-15), 0.92 (s, $\left.\mathrm{H}_{3}-14\right) ;{ }^{13} \mathrm{C}$ NMR $\left(125 \mathrm{MHz}, \mathrm{CDCl}_{3}\right) \delta 165.9\left(\mathrm{C}-1^{\prime}\right), 146.7$ (C-3'), 136.8 (C-9), 121.4 (C-10), 120.2 (C-2'), 82.6 (C-2), 77.0 (C-7), 74.8 C-4), 74.6 (C-12), 72.5 (C-8), 69.7 (C-11), 66.7 (C-13), 50.1 (C-5), 38.9 (C-6), 37.3 (C-3), 20.7 (C-16), 15.8 (C-15), 15.7 (C-4'), 6.7 (C-14); HMBC data, H-2 $\rightarrow$ C-5, C-11, C-12; $\mathrm{H}_{2}-3 \rightarrow$ C-2, C-4; H-4 $\rightarrow$ C-1', C-2, C-5, C-6, 
C-12; H-7 $\rightarrow$ C-5, C-8, C-7; H-8 $\rightarrow$ C-6, C-7, C-9, C-10, C-16; H-10 $\rightarrow$ C-6, C-8, C-11, $\mathrm{C}-16$; H-11 $\rightarrow$ C-2, C-9, C-10; $\mathrm{H}_{2}-13 \rightarrow \mathrm{C}-2$, C-5, C-12; $\mathrm{H}_{3}-14 \rightarrow \mathrm{C}-4, \mathrm{C}-5, \mathrm{C}-6$; $\mathrm{H}_{3}-15 \rightarrow$ C-5, C-6; H $3_{3}-16 \rightarrow$ C-8, C-9, C-10; H-2' $\rightarrow$ C-1', C-4'; H-3' $\rightarrow$ C-1', C-4'; $\mathrm{H}_{3}-4^{\prime} \rightarrow$ C-1', $\mathrm{C}-2^{\prime}$; HRESIMS $m / z 373.1620[\mathrm{M}+\mathrm{Na}]+$, calcd. for $\mathrm{C}_{19} \mathrm{H}_{26} \mathrm{O}_{6} \mathrm{Na}, 373.1622$.

Guangomide $\mathbf{A}(5)-[\alpha]^{\mathrm{D}_{25}}+6.5\left(c 0.31, \mathrm{CHCl}_{3}\right) ;{ }^{1} \mathrm{H}$ and ${ }^{13} \mathrm{C}$ NMR data matched the literature; ${ }^{3}$ HRMALDITOFMS $m / z, 641.3163[\mathrm{M}+\mathrm{Na}]^{+}$, calcd for $\mathrm{C}_{31} \mathrm{H}_{46} \mathrm{~N}_{4} \mathrm{O}_{9} \mathrm{Na}$, 641.3157.

\section{Amino Acid Analysis by Chiral HPLC. ${ }^{13-15}$}

Independently, an aliquot of compounds $\mathbf{1}(2 \mathrm{mg})$ and $\mathbf{2}(2 \mathrm{mg})$ were subjected to hydrolysis with $6 \mathrm{~N} \mathrm{HCl}(1 \mathrm{~mL})$ in a sealed tube at $100{ }^{\circ} \mathrm{C}$ for $24 \mathrm{~h}$. Upon cooling, the solutions were evaporated to dryness. Each residue was dissolved in $\mathrm{H}_{2} \mathrm{O}$ and extracted with diethyl ether $(2 \times 2 \mathrm{~mL})$. Both organic and aqueous solutions were subjected to chiral HPLC analysis at a flow rate of $1.0 \mathrm{~mL} / \mathrm{min}$ using four different solvent systems: (1) $5 \%$ isopropanol in $2 \mathrm{mM}$ $\mathrm{CuSO}_{4}$ : L-Hiv $\left(t_{\mathrm{R}}=15 \mathrm{~min}\right)$, D-Hiv $\left(t_{\mathrm{R}}=27 \mathrm{~min}\right), \mathrm{L}-\mathrm{Hic}\left(t_{\mathrm{R}}=49 \mathrm{~min}\right), \mathrm{D}-\mathrm{Hic}\left(t_{\mathrm{R}}=68\right.$ min), L-NMeLeu ( $t_{\mathrm{R}}=12 \mathrm{~min}$ ), D-NMeLeu ( $\left.t_{\mathrm{R}}=17 \mathrm{~min}\right)$; (2) $5 \% \mathrm{MeOH}$ in $2 \mathrm{mM} \mathrm{CuSO}_{4}$ : L-Ser $\left(t_{\mathrm{R}}=4.9 \mathrm{~min}\right)$, D-Ser $\left(t_{\mathrm{R}}=5.3 \mathrm{~min}\right)$; (3) $30 \% \mathrm{MeOH}$ in $2 \mathrm{mM} \mathrm{CuSO}_{4}$ : L-Phe $\left(t_{\mathrm{R}}=25\right.$ $\mathrm{min})$, D-Phe ( $\left.t_{\mathrm{R}}=35 \mathrm{~min}\right)$, L-Leu $\left(t_{\mathrm{R}}=15 \mathrm{~min}\right)$, D-Leu $\left(t_{\mathrm{R}}=18 \mathrm{~min}\right) ;(4) 100 \% 1 \mathrm{mM}$ $\mathrm{CuSO}_{4}$ : L-Val $\left(t_{\mathrm{R}}=26 \mathrm{~min}\right), \mathrm{D}-\mathrm{Val}\left(t_{\mathrm{R}}=47 \mathrm{~min}\right)$. Dilutions were adjusted in each case to approximate the response of the UV detector $(\lambda=214 \mathrm{~nm})$ with those of hydrolyzed samples.

\section{Amino Acid Analysis of Marfey's Derivatives ${ }^{23}$ by UPLC}

A sample of compound $\mathbf{5}(2.3 \mathrm{mg})$ was subjected to acid hydrolysis in a manner similar to the above. The dried aqueous solution was re-suspended in $\mathrm{H}_{2} \mathrm{O}(100 \mu \mathrm{L})$ and $1 \%$ Marfey's reagent in acetone $(200 \mu \mathrm{L})$ and $1 \mathrm{M} \mathrm{NaHCO}_{3}(40 \mu \mathrm{L})$ were added. The mixture was heated at $40{ }^{\circ} \mathrm{C}$ for $1 \mathrm{~h}$ in a shaking water bath, after which it was removed and cooled. The mixture was quenched with $2 \mathrm{M} \mathrm{HCl}(20 \mu \mathrm{L})$, dried, and dissolved in MeOH for UPLC analysis. Amino acid standards (1 mg each) were derivatized with Marfey's reagent in a manner similar to the above. The UPLC analysis was performed using two solvent systems: (1) 10$50 \% \mathrm{CH}_{3} \mathrm{CN}-0.1 \%$ TFA in $\mathrm{H}_{2} \mathrm{O}$ over 10 min at a flow rate of $0.5 \mathrm{~mL} / \mathrm{min}$ : L-NMePhe $\left(t_{\mathrm{R}}=\right.$ $8.334 \mathrm{~min})$, D-NMePhe $\left(t_{\mathrm{R}}=8.447 \mathrm{~min}\right), \mathrm{L}-\mathrm{Ala}\left(t_{\mathrm{R}}=5.281 \mathrm{~min}\right)$, D-Ala $\left(t_{\mathrm{R}}=6.186 \mathrm{~min}\right)$; (2) $10-70 \% \mathrm{MeOH}-0.1 \%$ TFA in $\mathrm{H}_{2} \mathrm{O}$ over $10 \mathrm{~min}$ at a flow rate of $0.4 \mathrm{~mL} / \mathrm{min}$ : L-NMeAla $\left(t_{\mathrm{R}}=7.730 \mathrm{~min}\right), \mathrm{D}-\mathrm{NMeAla}\left(t_{\mathrm{R}}=7.682 \mathrm{~min}\right), \mathrm{L}-\mathrm{Ala}\left(t_{\mathrm{R}}=6.836 \mathrm{~min}\right), \mathrm{D}-\mathrm{Ala}\left(t_{\mathrm{R}}=8.067\right.$ min).

\section{Cytotoxicity Assay}

The cytotoxicity measurements against MCF- $7^{24}$ human breast carcinoma (Barbara A. Karmanos Cancer Center, Detroit, MI), NCI-H460 25 human large cell lung carcinoma (HTB-177, American Type Culture Collection, Manassas, VA), and SF-268 ${ }^{26}$ human astrocytoma (NCI Developmental Therapeutics Program, Frederick, MD) cell lines were performed as described previously. ${ }^{22}$ Compounds $\mathbf{1}$ and $\mathbf{2}$ were also tested against the HT-2927 human colorectal adenocarcinoma (HTB-38, American Type Culture Collection, Manassas, VA) and MDA-MB-435 ${ }^{28}$ human melanoma (HTB-129, American Type Culture Collection, Manassas, VA) cell lines as described previously. ${ }^{29}$

\section{Supplementary Material}

Refer to Web version on PubMed Central for supplementary material. 


\section{Acknowledgments}

This research was supported by P01 CA125066 from the National Cancer Institute/National Institutes of Health, Bethesda, MD. The Golden LEAF Foundation (Rocky Mount, NC) provided partial support to D. J. K. Mycology technical support was provided by Blaise Darveaux and Maurica Lawrence. HRMS data were acquired by the David H. Murdock Research Institute, Kannapolis, NC, and the Mass Spectrometry Research Group at Research Triangle Institute, Research Triangle Park, NC. We thank Dr. Cynthia S. Day of Wake Forest University for the Xray crystallographic data acquired for compound 5 .

\section{References}

1. Kinghorn AD, Carache de Blanco EJ, Chai HB, Orjala J, Farnsworth NR, Soejarto DD, Oberlies NH, Wani MC, Kroll DJ, Pearce CJ, Swanson SM, Kramer RA, Rose WC, Fairchild CR, Vite GD, Emanuel S, Jarjoura D, Cope FO. Pure Appl Chem. 2009; 81:1051-1063. [PubMed: 20046887]

2. Orjala, J.; Oberlies, NH.; Pearce, CJ.; Swanson, SM.; Kinghorn, AD. Bioactive Compounds from Natural Sources. In: Tringali, C., editor. Natural Products as Lead Compounds in Drug Discovery. 2. Taylor \& Francis; London, UK: 2011. p. 37-63.

3. Amagata T, Morinaka BI, Amagata A, Tenney K, Valeriote FA, Lobkovsky E, Clardy J, Crews P. J Nat Prod. 2006; 69:1560-1565. [PubMed: 17125221]

4. Cole, RJ.; Jarvis, BB.; Schweikert, MA. Handbook of Secondary Fungal Metabolites. Vol. 3. Academic Press; Amsterdam; Boston: 2003. p. xip. 672

5. Kawamura H, Pulici M, Koshino H, Esumi Y, Uzawa J, Kumagai H, Sugawara F. Nat Prod Letts. 2000; 14:299-304.

6. Tsunoo A, Kamijo M, Taketomo N, Sato Y, Ajisaka K. J Antibiot. 1997; 50:1007-1013. [PubMed: 9510906]

7. Kwon BM, Nam JY, Lee SH, Jeong TS, Kim SU, Son KH, Kim YK, Han KH, Kim SK, Bok SH. Tetrahedron Lett. 1995; 36:6487-6490.

8. Dockerill B, Hanson JR, Siverns M. Phytochemistry. 1978; 17:572-573.

9. Nozoe S, Machida Y. Tetrahedron. 1972; 28:5105-5111.

10. Machida Y, Nozoe S. Tetrahedron. 1972; 28:5113-5117.

11. Guttorms R, Main P, Allison AJ, Overton KH. J Chem Soc Chem Commun. 1970:719-720.

12. Scott AI, Young DW, Hutchinson SA, Bhacca NS. Tetrahedron Lett. 1964:849-854.

13. Isaka M, Palasarn S, Sriklung K, Kocharin K. J Nat Prod. 2005; 68:1680-1682. [PubMed: 16309324]

14. Matthew S, Schupp PJ, Luesch H. J Nat Prod. 2008; 71:1113-1116. [PubMed: 18461997]

15. Pettit GR, Tan R. J Nat Prod. 2005; 68:60-63. [PubMed: 15679318]

16. Anderson MG, Jarman TB, Rickards RW. J Antibiot. 1995; 48:391-398. [PubMed: 7797441]

17. Gyimesi, Melera A. Tetrahedron Lett. 1967:1665-1673.

18. Flesch P, Stockinger G. Fresenius J Anal Chem. 1988; 330:152-154.

19. Ellison RA, Kotsonis FN. J Org Chem. 1976; 41:576-578. [PubMed: 1245914]

20. Iida A, Konishi K, Kubo H, Tomioka K, Tokuda H, Nishino H. Tetrahedron Lett. 1996; 37:92199220.

21. Sy-Cordero AA, Graf TN, Wani MC, Kroll DJ, Pearce CJ, Oberlies NH. J Antibiot. 2010; 63:539544. [PubMed: 20648023]

22. Li C, Lee D, Graf TN, Phifer SS, Nakanishi Y, Riswan S, Setyowati FM, Saribi AM, Soejarto DD, Farnsworth NR, Falkinham JO III, Kroll DJ, Kinghorn AD, Wani MC, Oberlies NH. J Nat Prod. 2009; 72:1949-1953. [PubMed: 19874044]

23. Marfey P. Carlsberg Res Commun. 1984; 49:591-596.

24. Soule HD, Vazguez J, Long A, Albert S, Brennan M. J Natl Cancer Inst. 1973; 51:1409-1416. [PubMed: 4357757]

25. Carney DN, Gazdar AF, Bunn PA Jr, Guccion JG. Stem Cells. 1982; 1:149-164. [PubMed: 6294885] 
26. Rosenblum ML, Gerosa MA, Wilson CB, Barger GR, Pertuiset BF, de Tribolet N, Dougherty DV. J Neurosurg. 1983; 58:170-176. [PubMed: 6848672]

27. Fogh, J.; Trempe, G. Human Tumor Cells In Vitro. Plenum; New York, USA: 1975. p. 115-159.

28. Rae JM, Creighton CJ, Meck JM, Haddad BR, Johnson MD. Breast Cancer Res Treat. 2007; 104:13-19. [PubMed: 17004106]

29. Ayers S, Graf TN, Adcock AF, Kroll DJ, Matthew S, Carache de Blanco EJ, Shen Q, Swanson SM, Wani MC, Pearce CJ, Oberlies NH. J Nat Prod. 2011; 74:1126-1131. [PubMed: 21513293] 


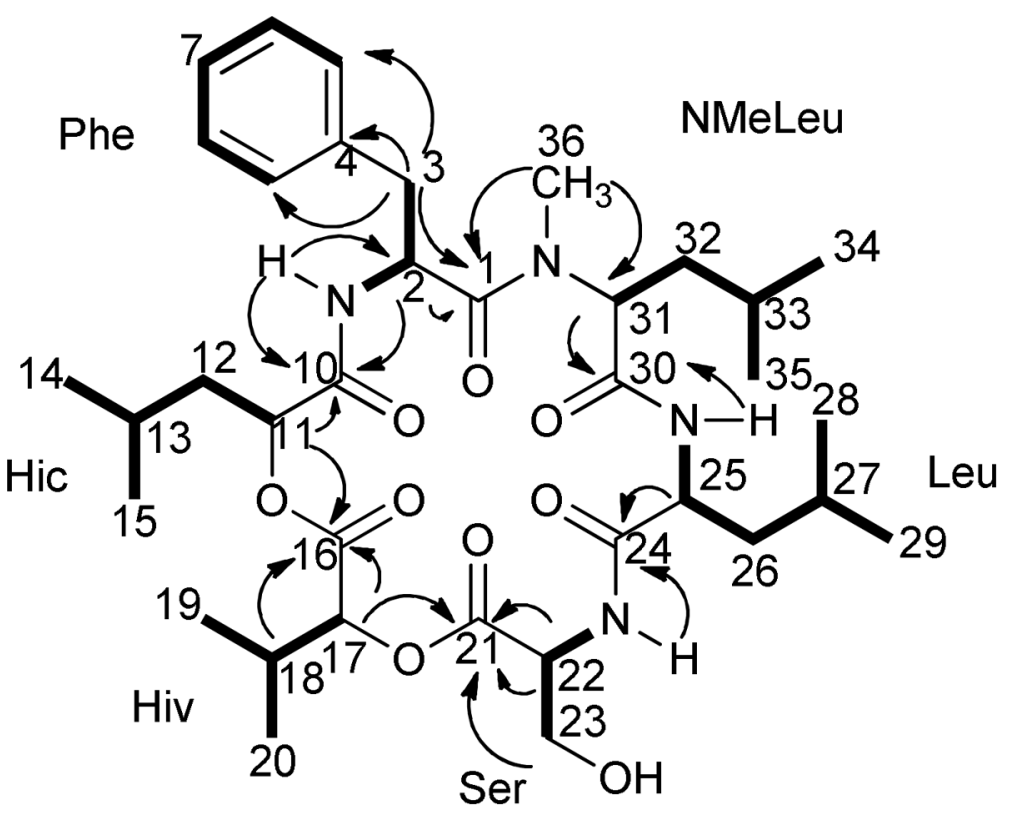

Figure 1.

Selected HMBC $(\rightarrow)$ and COSY ( - ) correlations for $\mathbf{1}$. 


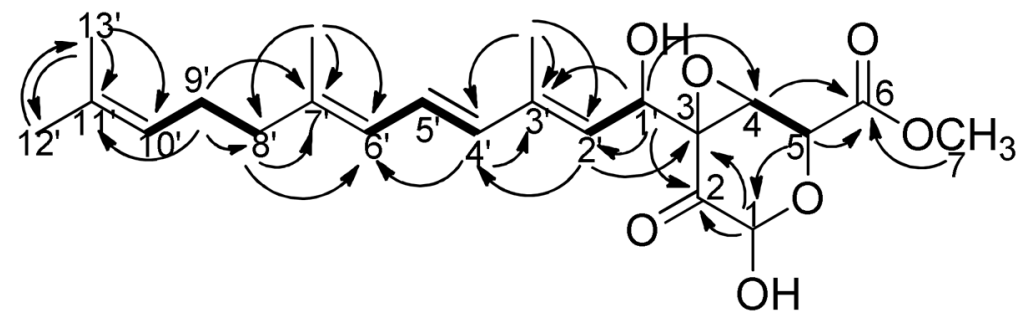

Figure 2.

Selected HMBC $(\rightarrow)$ and COSY ( - ) correlations for 3. 
Table 1

NMR Data for Compounds 1 and $2\left(500 \mathrm{MHz}\right.$ for ${ }^{1} \mathrm{H}, 125 \mathrm{MHz}$ for ${ }^{13} \mathrm{C}$; chemical shifts in $\delta$, coupling constants in $\mathrm{Hz}, \mathrm{CDCl}_{3}$ )

\begin{tabular}{|c|c|c|c|c|}
\hline \multirow[b]{2}{*}{ Position } & \multicolumn{2}{|c|}{ Compound 1} & \multicolumn{2}{|l|}{ Compound 2} \\
\hline & $\delta_{\mathrm{H}}$ mult $(J$ in $\mathrm{Hz})$ & $\delta_{\mathrm{C}}$ & $\delta_{\mathrm{H}}$ mult $(J$ in $\mathrm{Hz})$ & $\delta_{\mathrm{C}}$ \\
\hline 1 & & 172.4 & & 172.8 \\
\hline 2 & 5.29, ddd $(5,9,10)$ & 50.1 & 5.27, ddd $(5,9,10)$ & 50.4 \\
\hline 3 & $\begin{array}{l}2.84, \mathrm{dd}(10,13) \\
2.98, \mathrm{dd}(5,13)\end{array}$ & 39.5 & $\begin{array}{l}2.83, \mathrm{dd}(10,13) \\
3.05, \mathrm{~d}(5)\end{array}$ & 39.7 \\
\hline 4 & & 135.8 & & 135.8 \\
\hline 5 & $7.19-7.26, \mathrm{~m}$ & 129.4 & $7.22-7.28, \mathrm{~m}$ & 129.5 \\
\hline 6 & $7.19-7.26, \mathrm{~m}$ & 128.5 & $7.22-7.28, \mathrm{~m}$ & 128.7 \\
\hline 7 & $7.19-7.26, \mathrm{~m}$ & 127.1 & $7.22-7.28, \mathrm{~m}$ & 127.2 \\
\hline 8 & $7.19-7.26, \mathrm{~m}$ & 128.5 & $7.22-7.28, \mathrm{~m}$ & 128.7 \\
\hline 9 & $7.19-7.26, \mathrm{~m}$ & 129.4 & $7.22-7.28, \mathrm{~m}$ & 129.5 \\
\hline $\mathrm{NH}$ & $7.46, d(9)$ & & $7.42, \mathrm{~d}(9)$ & \\
\hline 10 & & 169.7 & & 169.9 \\
\hline 11 & $5.45, \mathrm{dd}(5,8)$ & 73.5 & $5.45, \mathrm{dd}(5,9)$ & 73.5 \\
\hline 12 & $1.53-1.71, \mathrm{~m}$ & 42.0 & $1.51-1.71, \mathrm{~m}$ & 42.0 \\
\hline 13 & $1.53-1.71, \mathrm{~m}$ & 24.4 & $1.51-1.71, \mathrm{~m}$ & 24.5 \\
\hline 14 & $0.91, \mathrm{~d}(7)$ & 23.0 & $0.93, \mathrm{~d}(7)$ & 23.2 \\
\hline 15 & $0.90, \mathrm{~d}(6)$ & 22.0 & $0.92, \mathrm{~d}(6)$ & 22.1 \\
\hline 16 & & 167.8 & & 168.0 \\
\hline 17 & $4.65, \mathrm{~d}(5)$ & 79.0 & $4.66, \mathrm{~d}(5)$ & 79.1 \\
\hline 18 & $2.26, \mathrm{~m}$ & 30.4 & $2.26, \mathrm{~m}$ & 30.5 \\
\hline 19 & $1.02, \mathrm{~d}(6)$ & 17.5 & $1.03, \mathrm{~d}(7)$ & 17.6 \\
\hline 20 & $1.01, \mathrm{~d}(7)$ & 18.8 & $1.03, \mathrm{~d}(7)$ & 19.0 \\
\hline 21 & & 170.2 & & 170.2 \\
\hline 22 & $4.73, \mathrm{dt}(8,2)$ & 54.9 & $4.71, \mathrm{~d}(10)$ & 54.6 \\
\hline 23 & $\begin{array}{l}4.05, \mathrm{dt}(12,2) \\
4.21, \mathrm{dt}(2,12)\end{array}$ & 63.4 & $\begin{array}{l}4.03, \text { br. d (12) } \\
4.26, \mathrm{dt}(2,12)\end{array}$ & 64.1 \\
\hline $\mathrm{NH}$ & $7.93, \mathrm{~d}(8)$ & & $7.86, d(9)$ & \\
\hline $\mathrm{OH}$ & $4.87, \mathrm{dd}(12,2)$ & & $4.84, \mathrm{dt}(9,2)$ & \\
\hline 24 & & 171.9 & & 171.3 \\
\hline 25 & 4.52, ddd $(4,9,10)$ & 51.7 & $4.41, \mathrm{dd}(4,9)$ & 58.5 \\
\hline $26^{a}$ & $\begin{array}{l}1.95, \text { ddd }(4,9,14) \\
1.53-1.71, \mathrm{~m}\end{array}$ & 39.1 & & \\
\hline 27 & $1.53-1.71, \mathrm{~m}$ & 25.0 & $2.60, \mathrm{~m}$ & 28.0 \\
\hline 28 & $0.87, \mathrm{~d}(7)$ & 21.3 & $0.86, \mathrm{~d}(7)$ & 20.2 \\
\hline 29 & $0.93, d(7)$ & 23.3 & $0.97, \mathrm{~d}(7)$ & 17.2 \\
\hline $\mathrm{NH}$ & $5.92, \mathrm{~d}(9)$ & & $6.16, d(9)$ & \\
\hline 30 & & 170.5 & & 170.3 \\
\hline 31 & $3.45, \mathrm{dd}(5,10)$ & 65.1 & $3.47, \operatorname{dd}(7,9)$ & 65.7 \\
\hline
\end{tabular}




\begin{tabular}{clclc}
\hline & \multicolumn{2}{c}{ Compound 1 } & \multicolumn{2}{c}{ Compound 2 } \\
\cline { 2 - 5 } Position & $\boldsymbol{\delta}_{\mathbf{H}}$ mult $(\boldsymbol{J}$ in Hz) & $\boldsymbol{\delta}_{\mathbf{C}}$ & $\boldsymbol{\delta}_{\mathbf{H}}$ mult $(\boldsymbol{J}$ in Hz) & $\boldsymbol{\delta}_{\mathbf{C}}$ \\
\hline 32 & 1.34, ddd $(5,10,14)$ & 36.8 & 1.33, ddd $(5,9,14)$ & 37.0 \\
& $1.53-1.71, \mathrm{~m}$ & & $1.51-1.60, \mathrm{~m}$ & \\
33 & $1.53-1.71, \mathrm{~m}$ & 24.5 & $1.51-1.60, \mathrm{~m}$ & 24.7 \\
34 & $0.81, \mathrm{~d}(7)$ & 21.6 & $0.86, \mathrm{~d}(7)$ & 22.0 \\
35 & $0.78, \mathrm{~d}(6)$ & 23.6 & $0.81, \mathrm{~d}(6)$ & 23.4 \\
36 & $3.06, \mathrm{~s}$ & 40.9 & $3.03, \mathrm{~s}$ & 41.0 \\
\hline
\end{tabular}

${ }^{a}$ Position 26 is only present in compound $\mathbf{1}$. 